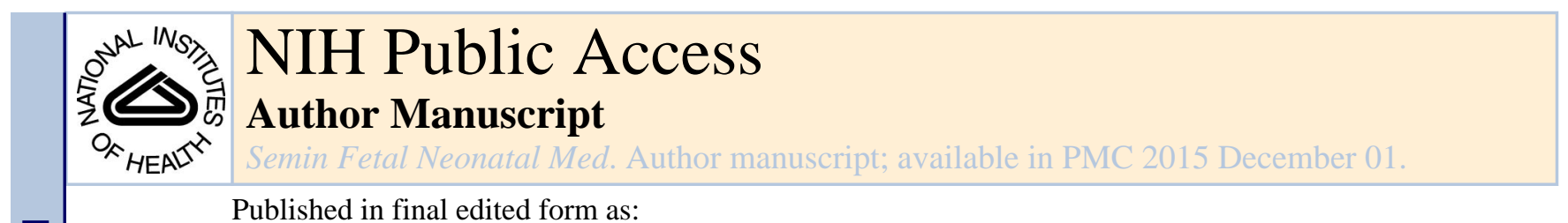

Published in final edited form as:

Semin Fetal Neonatal Med. 2014 December ; 19(6): 324-330. doi:10.1016/j.siny.2014.09.003.

\title{
Genetic causes of congenital diaphragmatic hernia
}

\author{
Julia Wynn, Lan Yu, and Wendy K. Chung* \\ Division of Molecular Genetics, Department of Pediatrics, Columbia University Medical Center, \\ New York, NY 10032, USA
}

\begin{abstract}
Congenital diaphragmatic hernia $(\mathrm{CDH})$ is a moderately prevalent birth defect that, despite advances in neonatal care, is still a significant cause of infant death, and surviving patients have significant morbidity. The goal of ongoing research to elucidate the genetic causes of $\mathrm{CDH}$ is to develop better treatment and ultimately prevention. $\mathrm{CDH}$ is a complex developmental defect that is etiologically heterogeneous. This review summarizes the recurrent genetic causes of CDH including aneuploidies, chromosome copy number variants, and single gene mutations. It also discusses strategies for genetic evaluation and genetic counseling in an era of rapidly evolving technologies in clinical genetic diagnostics.
\end{abstract}

\section{Keywords}

Congenital diaphragmatic hernia; Copy number variants; Gene; Genomics; Syndromes

\section{Introduction}

Congenital diaphragmatic hernia (CDH) occurs in 1 in 3000 live births, accounting for $8 \%$ of all birth defects and 1-2\% of infant mortality, making it one of the most prevalent and lethal congenital anomalies [1-3]. The diaphragm develops during the 4th-8th week of gestation, and the hernia is thought to occur when the pleuroperitoneal folds and septum transversum fail to converge and fuse. Posterior lateral hernias (Bodaleck) account for $>95 \%$ of neonatal diagnoses with $85 \%$ occurring on the left side [1,4]. Anterior retrosternal or parasternal CDHs (Morgagni) account for $\sim 2 \%$ of all $\mathrm{CDH}$ cases. Other rare types of hernias include an anterior hernia often associated with Pentalogy of Cantrell and a central hernia which involves a defect in the central tendon. Diaphragm eventration resulting from incomplete muscularization of the diaphragm is also included within the spectrum of $\mathrm{CDH}$. Approximately 50-80\% of CDHs are diagnosed in the prenatal period when the liver and intestines are visualized in the chest with a malpositioned heart. $\mathrm{CDH}$ may occur as an

() 2014 Elsevier Ltd. All rights reserved.

"Corresponding author. Address: Division of Molecular Genetics, Department of Pediatrics, Columbia University Medical Center, 1150 St Nicholas Avenue, Room 620, New York, NY 10032, USA. Tel.: +1 212-851-5313; fax: +1 212-851-5306. wkc15@columbia.edu (W.K. Chung).

Publisher's Disclaimer: This is a PDF file of an unedited manuscript that has been accepted for publication. As a service to our customers we are providing this early version of the manuscript. The manuscript will undergo copyediting, typesetting, and review of the resulting proof before it is published in its final citable form. Please note that during the production process errors may be discovered which could affect the content, and all legal disclaimers that apply to the journal pertain. 
isolated defect, but $\sim 40 \%$ of $\mathrm{CDH}$ cases are non-isolated and have at least one additional anomaly $[5,6]$. The most frequent co-occurring defect is congenital heart disease (CHD) which is present in $\sim 20 \%$ of patients [4,6]. Birth defects of all other systems have also been described in $\mathrm{CDH}$ cases. In some cases, the constellation of birth defects is associated with a specific syndrome and may provide insight into the genetic etiology. More than 50 different genetic causes have been associated with $\mathrm{CDH}$, most in non-isolated cases, but, increasingly, genetic etiologies are being identified in isolated $\mathrm{CDH}$ cases. We review the most widespread chromosomal and monogenetic causes with $\mathrm{CDH}$ as a recognized feature.

\section{Genetics}

\subsection{Chromosomal}

Complete or mosaic chromosome aneuploidies, large chromosome deletions/duplications, and complex chromosome rearrangements identifiable by karyotype are present in 10-35\% of $\mathrm{CDH}$ cases and occur at greatest frequency in non-isolated, prenatally diagnosed cases [2,6-11]. An additional 3.5-13\% of cases without identifiable karyotype abnormalities have copy number variants (CNVs) including microdeletions or microduplications identifiable by chromosome microarray analysis, which offers higher resolution over a standard karyotype [12-20]. Aneuploidies and CNVs are associated with increased neonatal mortality $[12,18]$.

Aneuploidies, CNVs and cytogenetic rearrangements involving almost all chromosomes have been described with $\mathrm{CDH}$. Holder et al. published an exhaustive review of all reported cases of chromosome anomalies in $\mathrm{CDH}$ [21], and chromosome microarray analysis has expanded our understanding of recurrent CNVs associated with $\mathrm{CDH}$. We briefly review the aneuploidies associated with $\mathrm{CDH}$ and provide a more detailed discussion of recurrent CNVs. A complete list of all recurrent and newly reported CNVs is available in Supplementary Table S1.

\subsection{Aneuploidies}

The most prevalent aneuploidy associated with $\mathrm{CDH}$, trisomy 18 , occurs in $\sim 2-5 \%$ of $\mathrm{CDH}$ cases [2,7]. CDH has also been infrequently described in trisomy 13 , which accounts for $<1 \%$ of $\mathrm{CDH}$ cases $[2,7,10]$. Down syndrome is the most frequently occurring aneuploidy identified in children with a Morgagni hernia [22]. Other aneuploidies infrequently described with CDH include trisomy 9 [23], trisomy 16 [24], trisomy 22 [25], mosaic trisomy 2 [15], and mosaic trisomy 8 [7]. Sex aneuploidies including Turner syndrome $(45, X)[10]$ and trisomy X $(46, X X X)[6]$ have also rarely been described with CDH. With the exception of the sex aneuploidies, complete aneuploidies are often diagnosed prenatally or in the neonatal period by the presence of associated birth defects and dysmorphic features.

\subsection{Copy number variants}

2.3.1. Tetrasomy 12p, Pallister-Killian syndrome (OMIM: 601803)—PallisterKillian syndrome (PKS), or mosaic tetrasomy 12p, is one of the more widespread chromosome disorders associated with CDH. PKS is caused by mosaic isochromosome $12 \mathrm{p}$. Whereas the isochromsome is detectible by karyotype, PKS can be a difficult molecular 
diagnosis to make as the isochromosome $12 \mathrm{p}$ does not culture in standard blood (lymphocytes) and is usually only found in a karyotype of cells from amniocentesis, buccal swab, or skin biopsy [26]. Up to $50 \%$ of PKS cases have a CDH, and PKS accounts for 2$5 \%$ of $\mathrm{CDH}$ cases [27]. Other common features of PKS include central nervous system (CNS) anomalies, shortened limbs, coarse facial features, and some degree of intellectual disability.

2.3.2. 8p23.1 deletion syndrome (OMIM: 222400)—The 8p23.1 deletion syndrome accounts for $3-5 \%$ of $\mathrm{CDH}$ cases $[12,16,28]$. A CDH is present in $~ 50 \%$ of cases and almost all cases have CHD. Additional anomalies include CNS anomalies, dysmorphic facial features, intellectual disability, and autism. The critical region for $\mathrm{CDH}$ is $3.7 \mathrm{Mb}$ encompassing base pairs 8,079,861-11,860,569 (hg19) [28]. This region includes two genes, GATA4 and SOX7, which have been implicated in the development of the diaphragm. GATA4 is a transcription factor important in heart and diaphragm development. Heterozygous knockout mouse have diaphragm defects [29]. The activation and expression of GATA4 is influenced by retinoids [30], and the retinoid signaling pathway is well known to be involved in diaphragm development [31]. Both inherited and de-novo mutations in GATA4 have been identified in isolated cases of $\mathrm{CDH}$ and of $\mathrm{CDH}$ with CHD [32]. SOX7 is also a transcription factor, and $S O X 7$ knockout mice have anterior $\mathrm{CDH}[28,33]$.

2.3.3. 15q26.1 deletion syndrome (OMIM: 142340)—The $15 \mathrm{q} 26.1$ deletion syndrome is associated with $\mathrm{CDH}$ and accounts for $1-2 \%$ of $\mathrm{CDH}$ cases $[12,17,19]$. This syndrome is associated with a broad spectrum of features including dysmorphic facial features, intrauterine growth restriction (IUGR), skeletal and digit anomalies, genitourinary abnormalities, imperforated anus, CHD, CNS anomalies, hypotonia, and behavior problems. $\mathrm{CDH}$ is estimated to occur in $\sim 10-30 \%$ of cases $[34,35]$. The critical region for $\mathrm{CDH}$ is a 1.8 Mb deletion encompassing base pairs $97,898,996$ to $99,682,477$ (hg19) [35]. COUP-TFII is a CDH candidate gene in this region. COUP-TFII encodes a transcriptional factor of the steroid/thyroid hormone receptor superfamily and is a downstream target of retinoid signaling [36]. Conditional knockout COUP-TFII in the gastric mesenchyme in mice results in $\mathrm{CDH}$ [37].

2.3.4. 1q41-42 deletion syndrome (OMIM: 612530)-The 1q41-42 deletion syndrome is associated with $\mathrm{CDH}$ in $30 \%$ of cases [38]. Other associated anomalies include CNS anomalies, seizures, intellectual disability, cleft palate, dysmorphic features, hypoplastic nails, club feet, and contractures of the limbs [38]. It accounts for $~ 1-3 \%$ of $\mathrm{CDH}$ cases [14,16,19]. A $4.7 \mathrm{Mb}$ deletion encompassing base pairs 219,914,853 to 224,637,114 (hg19) [39] is the critical region for CDH. DISPI and $H L X$ are candidate CDH genes. A de-novo mutation in DISPI was recently described in a child with CDH, VSD, cleft lip and palate, tethered cord, and hypotonia [40]. HLX knockout mice have CDH [41]. Missense variants in $H L X$ have been described in four cases of isolated CDH [39].

2.3.5. 8q23.1 deletions-Large ( $>30 \mathrm{Mb}$ ) de-novo deletions as well as small inherited microdeletions $(0.7-1 \mathrm{Mb})$ of $8 \mathrm{q} 23.1$ have been described in association with $\mathrm{CDH}$ $[8,16,42]$. The smallest microdeletion was a $700 \mathrm{~kb}$ deletion from base pairs 106,800,200- 
107,511,467 (hg19) [16] associated with IUGR and neonatal death, inherited from an apparently healthy mother. A paternally inherited $1 \mathrm{Mb}$ deletion at 8p23.1 was associated with eventration and intestinal malrotation [16]. Patients with larger deletions have additional anomalies including IUGR, shortened limbs with contractures, and dysmorphic facial features [8,42]. The ZFPM2/FOG2 gene is located at 8q23.1 and encodes a multizinc-finger transcriptional protein that regulates the expression of the GATA target genes [43]. It is a co-repressor for both COUP-TFII and GATA4 in the retinoid signaling pathway [44]. A mouse model with a hypomorphic ZFPM2/FOG2 allele has diaphragmatic defects [45]. De-novo and inherited autosomal dominant mutations in ZFPM2/FOG2 have been associated with isolated $\mathrm{CDH}$, and $\mathrm{CDH}$ with $\mathrm{CHD}$, and may account for up to $5 \%$ of the genetic causes of $\mathrm{CDH}$ [45-47].

2.3.6. 4p16 deletion, Wolf-Hirschhorn syndrome (OMIM: 194190)—The 4p16 deletion which causes Wolf-Hirschhorn syndrome (WHS) is infrequently reported with $\mathrm{CDH}$. Structural birth defects including CNS, cardiac, renal, or limb defects and CDH typically occur only in children with 4 p16 deletions $>5 \mathrm{Mb}$ [48]. Other features of WHS include characteristic facial features of a 'Greek warrior helmet' with high forehead, hypertelorism, high arched eyebrows, micrognathia with downturned corners of the mouth, intellectual disabilities, and growth delay.

2.3.7. 11q23.2 duplications-Partial trisomy 11 , resulting from the unbalanced translocations 11;22(q23.3;q11.2) [49], 11;12 (q23.3;q24.3) [50], and less frequently 11;13(q23.2;q12.3) [51], has been associated with CDH. Additional anomalies include CNS anomalies, polydactyly, growth retardation and dysmorphic facial features.

2.3.8. Other recurrent CNVs-Several other microdeletion/microduplication syndromes have rarely been associated with $\mathrm{CDH}$. The 16p11.2 deletion/duplication is an autism susceptibility locus associated with a wide spectrum of neurocognitive manifestations. There have been several cases of $\mathrm{CDH}$ reported with the $16 \mathrm{p} 11.2$ deletion $[16,17,52]$. The $17 \mathrm{q} 12$ deletion was first identified to be associated with renal cysts, maturity onset diabetes of the young, and variable developmental delay. It has also been identified in several isolated CDH cases $[12,16]$.

\subsection{Single gene mutations}

Mutations in >20 different genes have been described in both syndromic and non-syndromic $\mathrm{CDH}$. This review will focus on syndromes with defined genetic bases. A complete list of all reported monogenetic etiologies associated with $\mathrm{CDH}$ is available in Supplementary Table $\mathrm{S} 2$.

\subsection{Autosomal recessive}

2.5.1. Donnai-Barrow syndrome (OMIM: 600073)—Donnai-Barrow syndrome (DBS)/facio-oculo-acoustico-renal (FOAR) is due to autosomal recessively inherited mutations in LRP2 [53]. CDH occurs in $>50 \%$ of DBS/FOAR cases [54]. Other features of DBS/FOAR syndrome include agenesis of the corpus callosum, developmental delay, enlarged anterior fontanel, myopia, hypertelorism, sensorineural hearing loss, and 
omphalocele. Low molecular weight proteinuria with elevated levels of retinol binding (RBP) and vitamin-D-binding proteins (DBP) is a cardinal feature [53]. LRP2 encodes megalin which is an endocytic transmembrane receptor that interacts with the sonic hedgehog (SHH) signaling pathway [55].

2.5.2. Matthew-Wood syndrome (OMIM: 6011186)—Matthew-Wood syndrome (MWS) is an autosomal recessive condition caused by mutations in STRA6 [56] and RARB [57]. MWS is associated with microphthalmia to anophthalmia, IUGR, cardiac and renal anomalies. Many cases of MWS have a diaphragm defect which ranges from complete agenesis to eventration of the diaphragm [56,58,59]. STRA6 belongs to a novel group of retinoic-acid-inducible genes [60]. Patients with MWS have also been found to have homozygous mutations in $R A R B$ [57]. RARB is one of a family of transcriptional transducers of the retinoid signaling pathway, and compound knockout mice of the RARB and RARA genes have diaphragm defects [61].

2.5.3. Cutis laxa (OMIM: 219100 and 613177)—Cutis laxa is a group of disorders characterized by loose and/or wrinkled skin. Some cases involve other body systems including the pulmonary, gastrointestinal, urinary, muscular and skeletal systems. Two cases of cutis laxa with $\mathrm{CDH}$ and other features including pulmonary artery stenosis, diverticulosis with tortuosity of the intestinal tract, joint laxity, hypotonia, and dysmorphic features were caused by autosomal recessive mutations in LTBP4 [62]. A patient with cutis laxa and CDH associated with a homozygous mutation in EFEMP2/FBLN4 has also been described [63].

2.5.4. Spondylocostal dysostosis (OMIM: 277300)—Spondylocostal dysostosis is within the spectrum of Jarcho-Levin syndrome and is characterized by multiple segmental defects of the vertebrae with additional features including short stature, kyphoscoliosis, respiratory compromise due to small chest size and infrequently $\mathrm{CDH}$. One patient with spondylocostal dysostosis with CDH and homozygous DLL3 mutations has been described [64].

\subsubsection{Other rare autosomal recessive conditions associated with $\mathrm{CDH}-$ There} is a single case of isolated $\mathrm{CDH}$ with an $86 \mathrm{~kb}$ deletion at 9p22.3 encompassing FREM1 and a splice mutation in the other copy of FREM1 [65]. This child had no features of the FREM1-related syndromes, which include bifid nose with anorectal and renal anomalies.

\subsection{Autosomal dominant}

2.6.1. WT1-opathies (OMIM: 194080)—Autosomal dominant mutations in WTI are associated with a spectrum of syndromes referred to as WT1-opathies. Denys-Drash syndrome (DDS) is the most common WT1-opathy associated with CDH [66]. DDS is associated with disorder of sexual development including retention of Müllerian structures and undervirilization of external genitalia in males and duplicated uterus and cervix in females as well as structural defects of the kidneys, progressive glomerulopathy, and predisposition to Wilms tumors. Up to 30\% of DDS patients have CDH [66]. DDS is associated with mutations in the DNA binding sites of WT1 [67,68]. CDH has also been infrequently described in association with other WT1-opathies including Meacham [69], 
Frasier syndrome [70], and WAGR (Wilms tumor, aniridia, genitourinary abnormalities, and mental retardation) [71]. WT1 encodes for a zinc-finger-containing protein which is involved in the retinoic acid signaling pathway. WTl knockout mice have defects of the diaphragm [72].

2.6.2. Cornelia de Lang syndrome (OMIM: 122470)—Cornelia de Lang syndrome (CdLS) is characterized by specific dysmorphic facial features including microbrachycephaly, highly arched eyebrows with synophrys and long eyelashes, anteverted nose with a long philtrum and thin upper lip with downturned corners of the mouth. Associated defects may include CHD, limb defects, IUGR, intellectual disability as well as $\mathrm{CDH}$. Mutations in NIPBL are the most common known cause of CdLS, and several cases of CdLS with CDH have been described with NIBPL mutations [73,74]. The NIPBL gene encodes a protein that is essential for segregation of homologous chromosomes during meiosis I and for repair of DNA double-strand breaks during G2 phase of mitosis [75].

2.6.3. Marfan syndrome (OMIM: 154700)—Marfan syndrome is an autosomal dominant connective tissue disorder caused by mutations in FBN1. CDH is not a feature of the classic presentation of Marfan syndrome, but several rare cases of severe neonatal Marfan syndrome have been associated with CDH [76-78]. Whereas classic Marfan syndrome is often inherited from an affected parent, neonatal Marfan syndrome is caused by de-novo mutations, typically in exons 24 and 25 of $F B N 1$ [79].

2.6.4. Other rare autosomal dominant conditions associated with $\mathrm{CDH}-$ One or more cases of the following autosomal dominant conditions have all been described with CDH: Kabuki syndrome with a mutation in KMT2D/MLL2 [80], Baller-Gerold/SaethreChötzen with a mutation in TWIST [81], Apert syndrome with craniosynostosis and an FGFR2 mutation [82], SHORT syndrome with a BMP4 mutation [83], tuberos sclerosis type 2 with a TSC2 mutation [84], Beckwith-Wiedemann syndrome with a paternally inherited $\operatorname{der}(4) \mathrm{t} t(4 ; 11)(\mathrm{q} 33 ; \mathrm{p} 14)$ [85], C-trigonocephaly [86], and multiple pterygium syndrome [87] without identified causes.

\subsection{X-linked}

2.7.1. Craniofrontonasal syndrome (OMIM: 304110)—Craniofrontonasal syndrome (CNFS) is an X-linked condition caused by mutations in EFNB1 characterized by coronal craniosynostosis, hypertelorism, bifid nasal tip, frontal bossing, scoliosis, and skeletal anomalies of the thorax and clavicles. Paradoxically, females are typically more severely affected than males. Several cases of CNFS with CDH have been described [88-90]. Both affected males and females have been reported with CDH. EFNBI encodes a member of the ephrin family of ligands. The eight ephrins are involved in cell migration and motility by interacting with adhesion proteins or altering cytoskeletal organization [91-93].

2.7.2. Simpson-Golabi-Behmel (OMIM: 312870)—Simpson-Golabi-Behmel (SGB) is an X-linked condition caused by mutations in $G D S$ characterized by pre- and postnatal macrosomia, syndactyly and polydactyly, pectus excavatum, club feet, vertebral anomalies, CHD and cardiac arrhythmias, renal anomalies, developmental delay and a predisposition to 
the development of embryonal tumors including Wilms tumor and hepatoblastoma. Several cases of SGB with GPC3 mutations have been described, and in one series CDH occurred in $18 \%(5 / 28)[94,95]$. The GPC3 protein is one of six glycosylphosphatidylinositol-linked cell surface heparan sulfate proteoglycans that function as cell surface receptors and modulate cellular responses to growth factors and other morphogens including fibroblast growth factors, bone morphogenetic proteins, and members of the SHH and Wnt gene families [96].

2.7.3. Focal dermal hypoplasia (OMIM: 305600)—The $X$-linked recessive condition focal dermal hypoplasia, also called Goltz-Gorlin, is caused by mutations in PORCN and is characterized by dermal linear pigmentation, fat herniation through skin, and ocular, digit, and teeth abnormalities. Several cases with CDH have been described [97-99]. PORCN encodes an endoplasmic reticulum transmembrane protein involved in processing of Wnt proteins [100]. A single case of Lowe syndrome caused by a mutation in OCRL1 was associated with $\mathrm{CDH}$, cataracts, learning difficulties, rickets, poor growth, and seizures [101].

2.7.4. Syndromes with unknown genetic etiologies-Fryns syndrome (OMIM: 229850) is a common clinical diagnosis for $\mathrm{CDH}$ cases associated with multiple congenital anomalies usually including dysmorphic features and limb defects. Some cases have been associated with CNVs associated with CDH (15q26.2, 1q41, 1q25). All modes of inheritance have been described, but no genes have been associated with Fryns syndrome, suggesting that it may be genetically heterogeneous. Gershoni-Baruch [102] and X-linked thoracoabdominal syndrome [103] have also been described to include $\mathrm{CDH}$, but the molecular etiology of these conditions is unknown.

\subsection{Non-syndromic single gene mutations}

In addition to single gene mutations in GAT4, ZFPM2/FOG2, and DIPS1, other rare single gene mutations have also been reported with $\mathrm{CDH}$. GATA6 mutations have been described in CDH cases with and without CHD [104]. MYH1O mutations have been identified in two children with $\mathrm{CDH}$. One child had an apparently isolated $\mathrm{CDH}$ and passed away in the neonatal period, and the other child had multiple congenital anomalies and intellectual disability [105]. It is anticipated that, with recent advances in comprehensive genomic sequencing technology, additional genes will be identified in both isolated and non-isolated $\mathrm{CDH}$, providing further insight into this genetically heterogeneous condition.

\subsection{Multifactorial}

Currently the cause of $\sim 80 \%$ of $\mathrm{CDH}$ cases remains unknown, demonstrating our limited understanding of the genetic etiologies of $\mathrm{CDH}$ as well as suggesting non-genetic, nonMendelian, or multifactorial etiologies for $\mathrm{CDH}$. A multifactorial inheritance and the possibility of epigenetic influences in $\mathrm{CDH}$ is supported by monozygotic twin studies showing, in one case series, $100 \%$ (5/5) discordance for CDH [7]. Studies of other birth defects such as CHD have suggested an oligogenic etiology [106] whereby multiple genetic variants all contribute to a developmental defect. Finally, although no specific environmental factor has clearly been associated with $\mathrm{CDH}$, the well-described involvement of retinol signaling pathway in diaphragm development raises the question of whether 
maternal retinol may affect the risk of $\mathrm{CDH}$. One study of nine $\mathrm{CDH}$ cases found lower levels of retinol and retinol-binding protein (RBP) in cases compared to their unaffected siblings, and the mothers of affected children had significantly higher levels of retinol and RBP than mothers of children without CDH [107].

\subsection{Genetic evaluation and counseling}

The identification of a genetic cause for the $\mathrm{CDH}$ provides important information about prognosis, management, and recurrence risk, and therefore a complete genetic evaluation including a physical examination, family history, and chromosome microarray is warranted for all cases of CDH. A karyotype in fibroblasts should be completed if PKS is suspected. Prenatally, families should be offered an amniocentesis since non-invasive methods such as cell-free fetal DNA do not provide a comprehensive genetic characterization.

Single gene analysis should be completed as indicated by the associated birth defects, dysmorphic features or family history. Presently, there is no laboratory offering testing for a panel of genes associated with $\mathrm{CDH}$, though this may be available in the future. An alternative to the gene-by-gene genetic evaluation is whole exome sequencing (WES). Recent studies have demonstrated the effectiveness of WES to detect genetic causes in CDH [104]. WES analyses should include the affected individual and both parents to increase the probability of identifying de-novo genetic events. As the turnaround time for clinical WES improves, this may provide an important part of the evaluation of newborns with $\mathrm{CDH}$.

In addition to providing information about the prognosis and care of the affected fetus/child, identification of the genetic etiology provides definitive information about the recurrence risk for the family. Recurrence risk is estimated to be $\sim 2 \%$ in families with no known family history in whom the genetic etiology is unknown $[108,109]$. When an inherited genetic cause is identified, the recurrence is dependent on the specific pattern of inheritance of the condition. A de-novo genetic cause has a $<1 \%$ recurrence risk. It is important to note that several of the autosomal dominant forms of $\mathrm{CDH}$ have been associated with reduced penetrance $[32,47,104]$. When the molecular etiology is identified, families can pursue prenatal testing or preimplantation genetic diagnosis for future pregnancies.

Even with a complete genetic evaluation, a cause will not be identified for the majority of $\mathrm{CDH}$ cases. A negative genetic evaluation in the absence of a family history of $\mathrm{CDH}$ is reassuring. Although we do not yet know all the monogenetic causes of $\mathrm{CDH}$, a negative evaluation decreases the risk of recurrence.

\section{Conclusion}

It is clear that there is significant heterogeneity in the cause of $\mathrm{CDH}$ and that we are in a period of rapid expansion of our knowledge of the genetic causes of $\mathrm{CDH}$. As we define the spectrum of genes associated with $\mathrm{CDH}$, we will be able to define common molecular causes of $\mathrm{CDH}$ and define the clinical syndromes associated with these genes to inform prognosis and guide treatment. 


\section{Supplementary Material}

Refer to Web version on PubMed Central for supplementary material.

\section{References}

1. Doyle NM, Lally KP. The CDH Study Group and advances in the clinical care of the patient with congenital diaphragmatic hernia. Semin Perinatol. 2004; 28:174-184. [PubMed: 15283097]

2. Tonks A, Wyldes M, Somerset DA, Dent K, Abhyankar A, Bagchi I, et al. Congenital malformations of the diaphragm: findings of the West Midlands Congenital Anomaly Register 1995 to 2000. Prenat Diagn. 2004; 24:596-604. [PubMed: 15305345]

3. Dott MM, Wong LY, Rasmussen SA. Population-based study of congenital diaphragmatic hernia: risk factors and survival in Metropolitan Atlanta, 1968-1999. Birth Defects Res, Clin Mol Teratol. 2003; 67A:261-267.

4. Wynn J, Krishnan U, Aspelund G, Zhang Y, Duong J, Stolar CJ, et al. Outcomes of congenital diaphragmatic hernia in the modern era of management. J Pediatr. 2013; 163:114-119. e1. [PubMed: 23375362]

5. Colvin J, Bower C, Dickinson JE, Sokol J. Outcomes of congenital diaphragmatic hernia: a population-based study in Western Australia. Pediatrics. 2005; 116:e356-e363. [PubMed: 16140678]

6. Zaiss I, Kehl S, Link K, Neff W, Schaible T, Sutterlin M, et al. Associated malformations in congenital diaphragmatic hernia. Am J Perinatol. 2011; 28:211-218. [PubMed: 20979012]

7. Pober BR, Lin A, Russell M, Ackerman KG, Chakravorty S, Strauss B, et al. Infants with Bochdalek diaphragmatic hernia: sibling precurrence and monozygotic twin discordance in a hospital-based malformation surveillance program. Am J Med Genet. 2005; 138A:81-88. [PubMed: 16094667]

8. Howe DT, Kilby MD, Sirry H, Barker GM, Roberts E, Davison EV, et al. Structural chromosome anomalies in congenital diaphragmatic hernia. Prenat Diagn. 1996; 16:1003-1009. [PubMed: 8953633]

9. Witters I, Legius E, Moerman P, Deprest J, Van Schoubroeck D, Timmerman D, et al. Associated malformations and chromosomal anomalies in 42 cases of prenatally diagnosed diaphragmatic hernia. Am J Med Genet. 2001; 103:278-282. [PubMed: 11746006]

10. Ruano R, Bunduki V, Silva MM, Yoshizaki CT, Tanuri U, Macksoud JG, et al. Prenatal diagnosis and perinatal outcome of 38 cases with congenital diaphragmatic hernia: 8-year experience of a tertiary Brazilian center. Clinics. 2006; 61:197-202. [PubMed: 16832551]

11. Beck C, Alkasi O, Nikischin W, Engler S, Caliebe A, Leuschner I, et al. Congenital diaphragmatic hernia, etiology and management, a 10-year analysis of a single center. Archs Gynecol Obstet. 2008; 277:55-63.

12. Yu L, Wynn J, Ma L, Guha S, Mychaliska GB, Crombleholme TM, et al. De novo copy number variants are associated with congenital diaphragmatic hernia. J Med Genet. 2012; 49:650-659. [PubMed: 23054247]

13. Klaassens M, van Dooren M, Eussen HJ, Douben H, den Dekker AT, Lee C, et al. Congenital diaphragmatic hernia and chromosome 15q26: determination of a candidate region by use of fluorescent in situ hybridization and array-based comparative genomic hybridization. Am J Hum Genet. 2005; 76:877-82. [PubMed: 15750894]

14. Kantarci S, Casavant D, Prada C, Russell M, Byrne J, Haug LW, et al. Findings from aCGH in patients with congenital diaphragmatic hernia $(\mathrm{CDH})$ : a possible locus for Fryns syndrome. Am J Med Genet. 2006; 140A:17-23. [PubMed: 16333846]

15. Srisupundit K, Brady PD, Devriendt K, Fryns JP, Cruz-Martinez R, Gratacos E, et al. Targeted array comparative genomic hybridisation (array CGH) identifies genomic imbalances associated with isolated congenital diaphragmatic hernia (CDH). Prenat Diagn. 2010; 30:1198-1206.

[PubMed: 21064195] 
16. Wat MJ, Veenma D, Hogue J, Holder AM, Yu Z, Wat JJ, et al. Genomic alterations that contribute to the development of isolated and non-isolated congenital diaphragmatic hernia. J Med Genet. 2011; 48:299-307. [PubMed: 21525063]

17. Brady PD, DeKoninck P, Fryns JP, Devriendt K, Deprest JA, Vermeesch JR. Identification of dosage-sensitive genes in fetuses referred with severe isolated congenital diaphragmatic hernia. Prenat Diagn. 2013; 33:1283-1292. [PubMed: 24122781]

18. Scott DA, Klaassens M, Holder AM, Lally KP, Fernandes CJ, Galjaard RJ, et al. Genome-wide oligonucleotide-based array comparative genome hybridization analysis of non-isolated congenital diaphragmatic hernia. Hum Mol Genet. 2007; 16:424-430. [PubMed: 17210672]

19. Slavotinek AM, Moshrefi A, Davis R, Leeth E, Schaeffer GB, Burchard GE, et al. Array comparative genomic hybridization in patients with congenital diaphragmatic hernia: mapping of four $\mathrm{CDH}$-critical regions and sequencing of candidate genes at 15q26.1-15q26.2. Eur J Hum Genet. 2006; 14:999-1008. [PubMed: 16736036]

20. Samangaya RA, Choudhri S, Murphy F, Zaidi T, Gillham JC, Morabito A. Outcomes of congenital diaphragmatic hernia: a 12-year experience. Prenat Diagn. 2012; 32:523-529. [PubMed: 22499217]

21. Holder AM, Klaassens M, Tibboel D, de Klein A, Lee B, Scott DA. Genetic factors in congenital diaphragmatic hernia. Am J Hum Genet. 2007; 80:825-845. [PubMed: 17436238]

22. Jetley NK, Al-Assiri AH, Al-Helal AS, Al-Bin Ali AM. Down's syndrome as a factor in the diagnosis, management, and outcome in patients of Morgagni hernia. J Pediatr Surg. 2011; 46:636-639. [PubMed: 21496530]

23. Chen CP, Chern SR, Cheng SJ, Chang TY, Yeh LF, Lee CC, et al. Second-trimester diagnosis of complete trisomy 9 associated with abnormal maternal serum screen results, open sacral spina bifida and congenital diaphragmatic hernia, and review of the literature. Prenat Diagn. 2004; 24:455-462. [PubMed: 15229846]

24. Johnson P, Duncan K, Blunt S, Bell G, Ali Z, Cox P, et al. Apparent confined placental mosaicism of trisomy 16 and multiple fetal anomalies: case report. Prenat Diagn. 2000; 20:417-421. [PubMed: 10820412]

25. Sepulveda W, Be C, Schnapp C, Roy M, Wimalasundera R. Second-trimester sonographic findings in trisomy 22: report of 3 cases and review of the literature. J Ultrasound Med. 2003; 22:12711275. [PubMed: 14620898]

26. Doray B, Girard-Lemaire F, Gasser B, Baldauf JJ, De Geeter B, Spizzo M, et al. Pallister-Killian syndrome: difficulties of prenatal diagnosis. Prenat Diagn. 2002; 22:470-477. [PubMed: 12116305]

27. Wilkens A, Liu H, Park K, Campbell LB, Jackson M, Kostanecka A, et al. Novel clinical manifestations in Pallister-Killian syndrome: comprehensive evaluation of 59 affected individuals and review of previously reported cases. Am J Med Genet. 2012; 158A:3002-3017. [PubMed: 23169767]

28. Longoni M, Lage K, Russell MK, Loscertales M, Abdul-Rahman OA, Baynam G, et al. Congenital diaphragmatic hernia interval on chromosome $8 \mathrm{p} 23.1$ characterized by genetics and protein interaction networks. Am J Med Genet. 2012; 158A:3148-3158. [PubMed: 23165946]

29. Jay PY, Bielinska M, Erlich JM, Mannisto S, Pu WT, Heikinheimo M, et al. Impaired mesenchymal cell function in Gata4 mutant mice leads to diaphragmatic hernias and primary lung defects. Dev Biol. 2007; 301:602-614. [PubMed: 17069789]

30. Kostetskii I, Jiang Y, Kostetskaia E, Yuan S, Evans T, Zile M. Retinoid signaling required for normal heart development regulates GATA-4 in a pathway distinct from cardiomyocyte differentiation. Dev Biol. 1999; 206:206-218. [PubMed: 9986733]

31. Goumy C, Gouas L, Marceau G, Coste K, Veronese L, Gallot D, et al. Retinoid pathway and congenital diaphragmatic hernia: hypothesis from the analysis of chromosomal abnormalities. Fetal Diagn Ther. 2010; 28:129-139. [PubMed: 20501978]

32. Yu L, Wynn J, Cheung YH, Shen Y, Mychaliska GB, Crombleholme TM, et al. Variants in GATA4 are a rare cause of familial and sporadic congenital diaphragmatic hernia. Hum Genet. 2013; 132:285-292. [PubMed: 23138528] 
33. Wat MJ, Beck TF, Hernandez-Garcia A, Yu Z, Veenma D, Garcia M, et al. Mouse model reveals the role of SOX7 in the development of congenital diaphragmatic hernia associated with recurrent deletions of 8p23.1. Hum Mol Genet. 2012; 21:4115-4125. [PubMed: 22723016]

34. Magoulas PL, El-Hattab AW. Chromosome 15q24 microdeletion syndrome. Orphanet J Rare Dis. 2012; 7:2. [PubMed: 22216833]

35. Mosca AL, Pinson L, Andrieux J, Copin H, Bigi N, Puechberty J, et al. Refining the critical region for congenital diaphragmatic hernia on chromosome $15 \mathrm{q} 26$ from the study of four fetuses. Prenat Diagn. 2011; 31:912-914. [PubMed: 21706508]

36. Jonk LJ, de Jonge ME, Pals CE, Wissink S, Vervaart JM, Schoorlemmer J, et al. Cloning and expression during development of three murine members of the COUP family of nuclear orphan receptors. Mechnms Dev. 1994; 47:81-97.

37. You LR, Takamoto N, Yu CT, Tanaka T, Kodama T, Demayo FJ, et al. Mouse lacking COUPTFII as an animal model of Bochdalek-type congenital diaphragmatic hernia. Proc Natl Acad Sci USA. 2005; 102:16351-16356. [PubMed: 16251273]

38. Shaffer LG, Theisen A, Bejjani BA, Ballif BC, Aylsworth AS, Lim C, et al. The discovery of microdeletion syndromes in the post-genomic era: review of the methodology and characterization of a new 1q41q42 microdeletion syndrome. Genet Med. 2007; 9:607-616. [PubMed: 17873649]

39. Slavotinek AM, Moshrefi A, Lopez Jiminez N, Chao R, Mendell A, Shaw GM, et al. Sequence variants in the HLX gene at chromosome 1q41-1q42 in patients with diaphragmatic hernia. Clin Genet. 2009; 75:429-439. [PubMed: 19459883]

40. Kantarci S, Ackerman KG, Russell MK, Longoni M, Sougnez C, Noonan KM, et al. Characterization of the chromosome 1q41q42.12 region, and the candidate gene DISP1, in patients with CDH. Am J Med Genet. 2010; 152A:2493-2504. [PubMed: 20799323]

41. Hentsch B, Lyons I, Li R, Hartley L, Lints TJ, Adams JM, et al. Hlx homeo box gene is essential for an inductive tissue interaction that drives expansion of embryonic liver and gut. Genes Dev. 1996; 10:70-79. [PubMed: 8557196]

42. Kuechler A, Buysse K, Clayton-Smith J, Le Caignec C, David A, Engels H, et al. Five patients with novel overlapping interstitial deletions in 8q22.2q22.3. Am J Med Genet. 2011; 155A:18571864. [PubMed: 21739578]

43. Ackerman KG, Wang J, Luo L, Fujiwara Y, Orkin SH, Beier DR. Gata4 is necessary for normal pulmonary lobar development. Am J Resp Cell Mol Biol. 2007; 36:391-397.

44. Huggins GS, Bacani CJ, Boltax J, Aikawa R, Leiden JM. Friend of GATA 2 physically interacts with chicken ovalbumin upstream promoter-TF2 (COUP-TF2) and COUP-TF3 and represses COUP-TF2-dependent activation of the atrial natriuretic factor promoter. J Biol Chem. 2001; 276:28029-28036. [PubMed: 11382775]

45. Ackerman KG, Herron BJ, Vargas SO, Huang H, Tevosian SG, Kochilas L, et al. Fog2 is required for normal diaphragm and lung development in mice and humans. PLoS Genet. 2005; 1:58-65. [PubMed: 16103912]

46. Bleyl SB, Moshrefi A, Shaw GM, Saijoh Y, Schoenwolf GC, Pennacchio LA, et al. Candidate genes for congenital diaphragmatic hernia from animal models: sequencing of FOG2 and PDGFRalpha reveals rare variants in diaphragmatic hernia patients. Eur J Hum Genet. 2007; 15:950-958. [PubMed: 17568391]

47. Longoni M, Russell MK, High FA, Darvishi K, Maalouf FI, Kashani A, et al. Prevalence and penetrance of ZFPM2 mutations and deletions causing congenital diaphragmatic hernia. Clin Genet. 2014 Apr 4. [Epub ahead of print].

48. Casaccia G, Mobili L, Braguglia A, Santoro F, Bagolan P. Distal 4p microdeletion in a case of Wolf-Hirschhorn syndrome with congenital diaphragmatic hernia. Birth Defects Res A, Clin Mol Teratol. 2006; 76:210-213. [PubMed: 16498629]

49. Iselius L, Lindsten J, Aurias A, Fraccaro M, Bastard C, Bottelli AM, et al. The 11q;22q translocation: a collaborative study of 20 new cases and analysis of 110 families. Hum Genet. 1983; 64:343-355. [PubMed: 6618487]

50. Klaassens M, Scott DA, van Dooren M, Hochstenbach R, Eussen HJ, Cai WW, et al. Congenital diaphragmatic hernia associated with duplication of 11q23-qter. Am J Med Genet. 2006; 140A: 1580-1586. [PubMed: 16770801] 
51. Park JP, McDermet MK, Doody AM, Marin-Padilla JM, Moeschler JB, Wurster-Hill DH. Familial $\mathrm{t}(11 ; 13)(\mathrm{q} 21 ; \mathrm{q} 14)$ and the duplication 11q, 13q phenotype. Am J Med Genet. 1993; 45:46-48. [PubMed: 8418658]

52. Fernandez BA, Roberts W, Chung B, Weksberg R, Meyn S, Szatmari P, et al. Phenotypic spectrum associated with de novo and inherited deletions and duplications at $16 \mathrm{p} 11.2$ in individuals ascertained for diagnosis of autism spectrum disorder. J Med Genet. 2010; 47:195-203. [PubMed: 19755429]

53. Kantarci S, Al-Gazali L, Hill RS, Donnai D, Black GC, Bieth E, et al. Mutations in LRP2, which encodes the multiligand receptor megalin, cause Donnai-Barrow and facio-oculo-acoustico-renal syndromes. Nature Genet. 2007; 39:957-959. [PubMed: 17632512]

54. Pober BR, Longoni M, Noonan KM. A review of Donnai-Barrow and facio-oculo-acoustico-renal (DB/FOAR) syndrome: clinical features and differential diagnosis. Birth Defects Res A, Clin Mol Teratol. 2009; 85:76-81. [PubMed: 19089858]

55. Christensen EI, Birn H. Megalin and cubilin: multifunctional endocytic receptors. Nature Rev, Mol Cell Biol. 2002; 3:256-266. [PubMed: 11994745]

56. Pasutto F, Sticht H, Hammersen G, Gillessen-Kaesbach G, Fitzpatrick DR, Nurnberg G, et al. Mutations in STRA6 cause a broad spectrum of malformations including anophthalmia, congenital heart defects, diaphragmatic hernia, alveolar capillary dysplasia, lung hypoplasia, and mental retardation. Am J Hum Genet. 2007; 80:550-560. [PubMed: 17273977]

57. Srour M, Chitayat D, Caron V, Chassaing N, Bitoun P, Patry L, et al. Recessive and dominant mutations in retinoic acid receptor beta in cases with microphthalmia and diaphragmatic hernia. Am J Hum Genet. 2013; 93:765-772. [PubMed: 24075189]

58. Chassaing N, Ragge N, Kariminejad A, Buffet A, Ghaderi-Sohi S, Martinovic J, et al. Mutation analysis of the STRA6 gene in isolated and non-isolated anophthalmia/microphthalmia. Clin Genet. 2013; 83:244-250. [PubMed: 22686418]

59. Chassaing N, Golzio C, Odent S, Lequeux L, Vigouroux A, Martinovic-Bouriel J, et al. Phenotypic spectrum of STRA6 mutations: from Matthew-Wood syndrome to non-lethal anophthalmia. Hum Mutat. 2009; 30:E673-E681. [PubMed: 19309693]

60. Bouillet P, Sapin V, Chazaud C, Messaddeq N, Decimo D, Dolle P, et al. Developmental expression pattern of Stra6, a retinoic acid-responsive gene encoding a new type of membrane protein. Mechs Dev. 1997; 63:173-186.

61. Mendelsohn C, Lohnes D, Decimo D, Lufkin T, LeMeur M, Chambon P, et al. Function of the retinoic acid receptors (RARs) during development (II). Multiple abnormalities at various stages of organogenesis in RAR double mutants. Development. 1994; 120:2749-2771. [PubMed: 7607068]

62. Urban Z, Hucthagowder V, Schurmann N, Todorovic V, Zilberberg L, Choi J, et al. Mutations in LTBP4 cause a syndrome of impaired pulmonary, gastrointestinal, genitourinary, musculoskeletal, and dermal development. Am J Hum Genet. 2009; 85:593-605. [PubMed: 19836010]

63. Hucthagowder V, Sausgruber N, Kim KH, Angle B, Marmorstein LY, Urban Z. Fibulin-4: a novel gene for an autosomal recessive cutis laxa syndrome. Am J Hum Genet. 2006; 78:1075-1080. [PubMed: 16685658]

64. Bulman MP, Kusumi K, Frayling TM, McKeown C, Garrett C, Lander ES, et al. Mutations in the human delta homologue, DLL3, cause axial skeletal defects in spondylocostal dysostosis. Nature Genet. 2000; 24:438-441. [PubMed: 10742114]

65. Beck TF, Veenma D, Shchelochkov OA, Yu Z, Kim BJ, Zaveri HP, et al. Deficiency of FRAS1related extracellular matrix 1 (FREM1) causes congenital diaphragmatic hernia in humans and mice. Hum Mol Genet. 2013; 22:1026-1038. [PubMed: 23221805]

66. Antonius T, van Bon B, Eggink A, van der Burgt I, Noordam K, van Heijst A. Denys- Drash syndrome and congenital diaphragmatic hernia: another case with the $1097 \mathrm{G} \rightarrow \mathrm{A}(\mathrm{Arg} 366 \mathrm{His})$ mutation. Am J Med Genet. 2008; 146A:496-499. [PubMed: 18203154]

67. Cho HY, Lee BS, Kang CH, Kim WH, Ha IS, Cheong HI, et al. Hydrothorax in a patient with Denys-Drash syndrome associated with a diaphragmatic defect. Pediatr Nephrol. 2006; 21:19091912. [PubMed: 16932893] 
68. Devriendt K, Deloof E, Moerman P, Legius E, Vanhole C, de Zegher F, et al. Diaphragmatic hernia in Denys-Drash syndrome. Am J Med Genet. 1995; 57:97-101. [PubMed: 7645607]

69. Suri M, Kelehan P, O’Neill D, Vadeyar S, Grant J, Ahmed SF, et al. WT1 mutations in Meacham syndrome suggest a coelomic mesothelial origin of the cardiac and diaphragmatic malformations. Am J Med Genet. 2007; 143A:2312-2320. [PubMed: 17853480]

70. Denamur E, Bocquet N, Baudouin V, Da Silva F, Veitia R, Peuchmaur M, et al. WT1 splice-site mutations are rarely associated with primary steroid-resistant focal and segmental glomerulosclerosis. Kidney Int. 2000; 57:1868-1872. [PubMed: 10792605]

71. Scott DA, Cooper ML, Stankiewicz P, Patel A, Potocki L, Cheung SW. Congenital diaphragmatic hernia in WAGR syndrome. Am J Med Genet. 2005; 134:430-433. [PubMed: 15779010]

72. Ijpenberg A, Perez-Pomares JM, Guadix JA, Carmona R, Portillo-Sanchez V, Macias D, et al. Wt1 and retinoic acid signaling are essential for stellate cell development and liver morphogenesis. Dev Biol. 2007; 312:157-170. [PubMed: 18028902]

73. Hosokawa S, Takahashi N, Kitajima H, Nakayama M, Kosaki K, Okamoto N. Brachmann-de Lange syndrome with congenital diaphragmatic hernia and NIPBL gene mutation. Congenital Anom. 2010; 50:129-132.

74. Wilmink FA, Papatsonis DN, Grijseels EW, Wessels MW. Cornelia de lange syndrome: a recognizable fetal phenotype. Fetal Diagn Ther. 2009; 26:50-53. [PubMed: 19816032]

75. Watrin E, Schleiffer A, Tanaka K, Eisenhaber F, Nasmyth K, Peters JM. Human Scc4 is required for cohesin binding to chromatin, sister-chromatid cohesion, and mitotic progression. Curr Biol. 2006; 16:863-874. [PubMed: 16682347]

76. Stheneur C, Faivre L, Collod-Beroud G, Gautier E, Binquet C, Bonithon-Kopp C, et al. Prognosis factors in probands with an FBN1 mutation diagnosed before the age of 1 year. Pediatr Res. 2011; 69:265-270. [PubMed: 21135753]

77. Jacobs AM, Toudjarska I, Racine A, Tsipouras P, Kilpatrick MW, Shanske A. A recurring FBN1 gene mutation in neonatal Marfan syndrome. Archs Pediatr Adolesc Med. 2002; 156:1081-1085.

78. Wenkoff MS. A review and case report. Salmonella typhimurium septicemia in foals. Can Vet J. 1973; 14:284-287. [PubMed: 4586646]

79. Revencu N, Quenum G, Detaille T, Verellen G, De Paepe A, Verellen-Dumoulin C. Congenital diaphragmatic eventration and bilateral uretero-hydronephrosis in a patient with neonatal Marfan syndrome caused by a mutation in exon 25 of the FBN1 gene and review of the literature. Eur J Pediatr. 2004; 163:33-37. [PubMed: 14586646]

80. Zarate YA, Zhan H, Jones JR. Infrequent manifestations of Kabuki syndrome in a patient with novel MLL2 mutation. Mol Syndromol. 2012; 3:180-184. [PubMed: 23239960]

81. Piard J, Collet C, Arbez-Gindre F, Nirhy-Lanto A, Van Maldergem L. Coronal craniosynostosis and radial ray hypoplasia: a third report of Twist mutation in a 33 weeks fetus with diaphragmatic hernia. Eur J Med Genet. 2012; 55:719-722. [PubMed: 22982246]

82. Bulfamante G, Gana S, Avagliano L, Fabietti I, Gentilin B, Lalatta F. Congenital diaphragmatic hernia as prenatal presentation of Apert syndrome. Prenat Diagn. 2011; 31:910-911. [PubMed: 21706505]

83. Reis LM, Tyler RC, Schilter KF, Abdul-Rahman O, Innis JW, Kozel BA, et al. BMP4 lossoffunction mutations in developmental eye disorders including SHORT syndrome. Hum Genet. 2011; 130:495-504. [PubMed: 21340693]

84. Niemi AK, Northrup H, Hudgins L, Bernstein JA. Horseshoe kidney and a rare TSC2 variant in two unrelated individuals with tuberous sclerosis complex. Am J Med Genet. 2011; 155A:2534 2537. [PubMed: 21910228]

85. Turleau C, de Grouchy J, Chavin-Colin F, Martelli H, Voyer M, Charlas R. Trisomy 11p15 and Beckwith-Wiedemann syndrome. A report of two cases. Hum Genet. 1984; 67:219-221. [PubMed: 6745943]

86. Addor MC, Stefanutti D, Farron F, Meinecke P, Lacombe D, Sarlangue J, et al. "C" trigonocephaly syndrome with diaphragmnatic hernia. Genet Couns. 1995; 6:113-120. [PubMed: 7546453]

87. Entezami M, Runkel S, Kunze J, Weitzel HK, Becker R. Prenatal diagnosis of a lethal multiple pterygium syndrome type II. Case report. Fetal Diagn Ther. 1998; 13:35-38. [PubMed: 9605614] 
88. Twigg SR, Kan R, Babbs C, Bochukova EG, Robertson SP, Wall SA, et al. Mutations of ephrin-B1 (EFNB1), a marker of tissue boundary formation, cause craniofrontonasal syndrome. Proc Natl Acad Sci USA. 2004; 101:8652-8657. [PubMed: 15166289]

89. Vasudevan PC, Twigg SR, Mulliken JB, Cook JA, Quarrell OW, Wilkie AO. Expanding the phenotype of craniofrontonasal syndrome: two unrelated boys with EFNB1 mutations and congenital diaphragmatic hernia. Eur J Hum Genet. 2006; 14:884-887. [PubMed: 16639408]

90. Hogue J, Shankar S, Perry H, Patel R, Vargervik K, Slavotinek A. A novel EFNB1 mutation (c. $712 \mathrm{delG}$ ) in a family with craniofrontonasal syndrome and diaphragmatic hernia. Am J Med Genet. 2010; 152A:2574-2577. [PubMed: 20734337]

91. Twigg SR, Babbs C, van den Elzen ME, Goriely A, Taylor S, McGowan SJ, et al. Cellular interference in craniofrontonasal syndrome: males mosaic for mutations in the X-linked EFNB1 gene are more severely affected than true hemizygotes. Hum Mol Genet. 2013; 22:1654-1662. [PubMed: 23335590]

92. Pasquale EB. Eph receptor signalling casts a wide net on cell behaviour. Nature Rev, Mol Cell Biol. 2005; 6:462-475. [PubMed: 15928710]

93. Davy A, Aubin J, Soriano P. Ephrin-B1 forward and reverse signaling are required during mouse development. Genes Dev. 2004; 18:572-583. [PubMed: 15037550]

94. Li M, Shuman C, Fei YL, Cutiongco E, Bender HA, Stevens C, et al. GPC3 mutation analysis in a spectrum of patients with overgrowth expands the phenotype of Simpson-Golabi-Behmel syndrome. Am J Med Genet. 2001; 102:161-168. [PubMed: 11477610]

95. Yano S, Baskin B, Bagheri A, Watanabe Y, Moseley K, Nishimura A, et al. Familial SimpsonGolabi-Behmel syndrome: studies of X-chromosome inactivation and clinical phenotypes in two female individuals with GPC3 mutations. Clin Genet. 2011; 80:466-471. [PubMed: 20950395]

96. Song HH, Shi W, Xiang YY, Filmus J. The loss of glypican-3 induces alterations in Wnt signaling. J Biol Chem. 2005; 280:2116-2125. [PubMed: 15537637]

97. Smigiel R, Jakubiak A, Lombardi MP, Jaworski W, Slezak R, Patkowski D, et al. Co-occurrence of severe Goltz-Gorlin syndrome and pentalogy of Cantrell - case report and review of the literature. Am J Med Genet. 2011; 155A:1102-1105. [PubMed: 21484999]

98. Dias C, Basto J, Pinho O, Barbedo C, Martins M, Bornholdt D, et al. A nonsense porcn mutation in severe focal dermal hypoplasia with natal teeth. Fetal Pediatr Pathol. 2010; 29:305-313. [PubMed: 20704476]

99. Maas SM, Lombardi MP, van Essen AJ, Wakeling EL, Castle B, Temple IK, et al. Phenotype and genotype in 17 patients with Goltz-Gorlin syndrome. J Med Genet. 2009; 46:716-720. [PubMed: 19586929]

100. Caricasole A, Ferraro T, Rimland JM, Terstappen GC. Molecular cloning and initial characterization of the MG61/PORC gene, the human homologue of the Drosophila segment polarity gene Porcupine. Gene. 2002; 288:147-157. [PubMed: 12034504]

101. Race HJ, Elhadi N, Holder SE. Congenital diaphragmatic hernia in Lowe syndrome: a rare association? Clin Dysmorphol. 2010; 19:226. [PubMed: 20823704]

102. Gershoni-Baruch R, Machoul I, Weiss Y, Blazer S. Unknown syndrome: radial ray defects, omphalocele, diaphragmatic hernia, and hepatic cyst. J Med Genet. 1990; 27:403-404. [PubMed: 2359107]

103. Cantrell JR, Haller JA, Ravitch MM. A syndrome of congenital defects involving the abdominal wall, sternum, diaphragm, pericardium, and heart. Surg Gynecol Obstet. 1958; 107:602-614. [PubMed: 13592660]

104. Yu L, Bennett JT, Wynn J, Carvill GL, Cheung YH, Shen Y, et al. Whole exome sequencing identifies de novo mutations in GATA6 associated with congenital diaphragmatic hernia. J Med Genet. 2014; 51:197-202. [PubMed: 24385578]

105. Tuzovic L, Yu L, Zeng W, Li X, Lu H, Lu H-M, et al. A human de novo mutation in MYH10 phenocopies the loss of function mutation in mice. Rare Dis. 2013; 1:e26144. [PubMed: 25003005]

106. Bittel DC, Zhou XG, Kibiryeva N, Fiedler S, O’Brien JE Jr, Marshall J, et al. Ultra highresolution gene centric genomic structural analysis of a non-syndromic congenital heart defect, Tetralogy of Fallot. PloS One. 2014; 9:e87472. [PubMed: 24498113] 
107. Major D, Cadenas M, Fournier L, Leclerc S, Lefebvre M, Cloutier R. Retinol status of newborn infants with congenital diaphragmatic hernia. Pediatr Surg Int. 1998; 13:547-549. [PubMed: 9799371]

108. Torfs CP, Curry CJ, Bateson TF, Honore LH. A population-based study of congenital diaphragmatic hernia. Teratology. 1992; 46:555-565. [PubMed: 1290156]

109. Norio R, Kaariainen H, Rapola J, Herva R, Kekomaki M. Familial congenital diaphragmatic defects: aspects of etiology, prenatal diagnosis, and treatment. Am J Med Genet. 1984; 17:471483. [PubMed: 6702899] 


\section{Practice points}

- Aneuploidies and chromosome copy number variants are present in 10-35\% of $\mathrm{CDH}$ cases and are more frequent in non-isolated cases.

- More than 20 different monogenetic disorders are associated with CDH.

- A complete genetic evaluation is appropriate for all CDH cases and has the potential to provide information about prognosis, management, and recurrence risk.

\section{Research directions}

- Comprehensive genomic characterization of large numbers of patients with both isolated and non-isolated cases of $\mathrm{CDH}$ will be necessary to identify the full spectrum of genes and mutations causing $\mathrm{CDH}$ to facilitate future clinical genetic testing. 